\title{
Effects of gas atmosphere, platelet-derived growth factor and leukemia inhibitory factor on cell numbers of rabbit embryos cultured in a protein-free medium
}

\author{
JR Giles *, RH Foote \\ Department of Animal Science, Cornell University, Ithaca, New York 14853-4801, USA
}

(Received 2 I July 1996; accepted 23 October 1996)

Summary - While culture conditions for embryos have improved, development in vitro is not equivalent to in vivo growth. Platelet-derived growth factor (PDGF), mouse (mLIF) or human (hLIF) leukemia inhibitory factor and $10 \%$ fetal bovine serum (FBS) added to protein-free culture medium, as well as two gas atmospheres were evaluated for their effect on rabbit embryo development. Adding PDGF, mLIF or hLIF to the culture medium did not result in detectable differences in total cell number for blastocysts. The culture of rabbit embryos under a gas atmosphere of $10 \% \mathrm{CO}_{2}: 5 \% \mathrm{O}_{2}: 85 \% \mathrm{~N}_{2}$ resulted in improved total cell numbers $(P<0.01)$ for blastocysts compared to those developing under $5 \% \mathrm{CO}_{2}: 95 \%$ air (230 vs 159 , respectively). Supplementing RD (RPMI-1640 and Dulbecco's MEM, 1:1) medium with $10 \%$ FBS improved the number of total cells ( $264 \mathrm{vs} 155$ ) and inner cell mass cells ( $71 \mathrm{vs} 47$ ). These results indicate that when defined culture conditions promote a high proportion of two-cell embryos developing into blastocysts, the addition of certain growth factors did not have a detectable beneficial effect, while 10\% FBS improved culture conditions.

rabbit blastocyst / inner cell mass cell / oxygen / PDGF / LIF

Résumé - Effet des conditions de culture (environnement gazeux, présence de PDGF et LIF) sur le développement d'embryons de lapin in vitro. L'objectif de ce travail est d'optimiser les conditions de culture in vitro pour les embryons de lapins. Aussi, les effets du facteur de croissance dérivé des plaquettes (PDGF), du facteur inhibiteur de la leucémie d'origine murine (mLIF) ou humaine (hLIF) et de $10 \%$ de sérum de veau fotal ont été étudiés. Deux environnements gazeux pendant la culture ont été également comparés. Aucun des traitements avec le PDGF et les LIF n'a affecté les nombres de cellules des blastocystes. En revanche, l'environnement $10 \% \mathrm{CO}_{2}: 5 \% \mathrm{O}_{2}: 85 \% \mathrm{~N}_{2}$ avait un effet favorable sur les effec-

\footnotetext{
* Correspondence and reprints
}

Tel: (607) 255 2866; fax: (607) 255 9829; e-mail: jrg9@ cornell.edv 
tifs cellulaires des blastocytes ( 230 cellules) par rapport à un gazage avec $5 \% \mathrm{CO}_{2}: 95 \%$ air (159 cellules). L'addition de sérum de veau fœtal avait également un effet bénéfique sur les nombres de cellules (264 versus 155 ) et sur le nombre de cellules du bouton embryonnaire (71 versus 47). Les résultats démontrent que dans un système de culture optimisé pour embryons de lapins, seul le sérum de veau fœtal (mais pas le PDGF et le LIF) améliore encore les résultats.

\section{blastocyste / lapin / oxygène / LIF / PDGF}

\section{INTRODUCTION}

The development of rabbit embryo culture has progressed from media containing plasma or serum to semi-defined media containing bovine serum albumin (BSA) and finally to defined media containing no macromolecules (reviewed by Kane, 1987; Carney and Foote, 1991). Although the majority of rabbit embryos cultured in these defined media will develop into blastocysts, the number of cells is reduced compared to embryos developing in vivo (Carney and Foote, 1990, 1991; Collas et al, 1991; Giles and Foote, 1995), indicating that the culture systems are suboptimal.

Improvements in total cell numbers have been accomplished by decreasing the oxygen concentration and/or increasing the carbon dioxide concentration of the gas atmosphere under which rabbit embryos are cultured (Hallden et al, 1992; Li and Foote, 1993; Farrell and Foote, 1995). Further improvements in in vitro development may be dependent on the identification and addition of biological factors produced in the oviducts during embryo development. In fact, the expression of ligand and receptor genes for many growth factors in preimplantation stage embryos or in the oviduct supports the claim for their involvement during early embryonic development (Rappolee et al, 1988; Watson et al, 1992; Schulz and Heyner, 1993). Two such factors are platelet-derived growth factor (PDGF) and leukemia inhibitory factor (LIF).
The addition of PDGF to the culture medium has been reported to enhance development of bovine embryos past the eight-to-16-cell stage (Larson et al, 1992; Thibodeaux et al, 1993) or to increase the proportion of embryos developing into blastocysts (Yang et al, 1993). Other investigators, however, have not observed a beneficial effect of PDGF on development of mouse embryos (Colver et al, 1991) or cow embryos (Flood et al, 1993). The LIF, a glycoprotein expressed on cultured mouse blastocysts (Murray et al, 1990) and in the uterine endometrial glands of mice by the fourth day of pregnancy, is maternally controlled and is essential for implantation (reviewed by Stewart, 1994). The addition of human LIF (hLIF) to the culture medium increased the number of eight-cell stage mouse embryos which hatched and increased the size of blastocyst outgrowths in vitro (Robertson et al, 1991; Lavranos et al, 1995). Similarly, the culture of embryos in the presence of hLIF resulted in fewer degenerate embryos and a greater proportion of hatched blastocysts in the sheep (Fry et al, 1992) and cow (Fukui and Matsuyama, 1994; Han et al, 1995). Furthermore, using an antibody to hLIF, Yang et al (1994) detected LIF in luminal epithelium of rabbit uteri.

The present study was designed to test the hypothesis that PDGF and human or mouse LIF (hLIF or mLIF) added to a defined protein-free medium could improve rabbit embryo development into blastocysts when cultured under different gas environments, in comparison with fetal bovine serum (FBS) in the medium. 


\section{MATERIALS AND METHODS}

\section{Animals, superovulation and embryo recovery}

Sexually mature Dutch-belted and an albino strain of Dutch-belted rabbits were superovulated as previously described (Kennelly and Foote, 1965). Semen was collected from fertile males and used for artificial insemination at the time of injection of luteinizing hormone $(\mathrm{LH}$; day $0, \mathrm{~d} 0)$ to induce ovulation. Embryos were collected, following midventral laparotomy, by flushing the oviducts with Dulbecco's phosphatebuffered saline (PBS; Gibco BRL, Grand Island, $\mathrm{NY})+0.1 \%$ polyvinyl alcohol (PVA; Sigma, St Louis, MO, USA) 24-26 h (predominantly two-cell but some four-cell embryos) or 48-50 h (16-cell embryos) after injection of LH.

\section{Embryo culture}

Embryos were cultured in $50 \mu \mathrm{L}$ droplets (five to seven embryos/droplet) of modified RD medium (Carney and Foote, 1991) overlaid with silicone medical fluid (Dow Corning, Midland, MI, USA) at $39^{\circ} \mathrm{C}$ under a humid gas atmosphere of $10 \% \mathrm{CO}_{2}: 5 \% \mathrm{O}_{2}: 85 \% \mathrm{~N}_{2}$ or $5 \% \mathrm{CO}_{2}: 95 \%$ air. Modifications of RD medium were the use of low-glucose Dulbecco's modified Eagle's medium (DMEM; Gibco BRL) and the addition of $0.1 \%$ PVA ( $\mathrm{Li}$ and Foote, 1993). The twocell with a few four-cell embryos were cultured for 3 days ( $d 4$ of development) with the exception of those in experiment 3 , which were cultured for 5 days (d6 of development). Sixteencell embryos in experiment 3 were cultured for 4 days (d6 of development). At the end of culture, the embryos were allocated for study with immunosurgery and differential staining procedures.

\section{Immunosurgery and differential staining}

Immunosurgery of blastocysts and differential labeling of trophectoderm (TE) cells and inner cell mass (ICM) cells was accomplished as previously described (Handyside and Hunter, 1984; Giles and Foote, 1995). Briefly, the mucin coat and zona pellucida were removed and the embryos were incubated with mouse-antirabbit serum in the absence of a complement, washed and treated with rabbit serum as a source of complement. Embryos were fixed, stained with bisbenzimide (Hoechst 33342, Sigma Chemical Co, St Louis, MO, USA) and propidium iodide (PI; Sigma), mounted on a glass slide and examined using a fluorescence microscope. The lysed TE cells should be permeable to bisbenzimide and PI and fluoresce pink, whereas the ICM cells, unaffected by the immunosurgery procedure, should be permeable only to bisbenzimide, resulting in blue nuclei.

\section{Experimental design}

Experiment 1 was a $3 \times 2$ factorial study designed to determine if embryo development could be enhanced by adding 0,1 or $5 \mathrm{ng} / \mathrm{mL}$ of recombinant human PDGF-BB (R \& D Systems, Minneapolis, MN, USA) to the protein-free culture medium. In addition, the effects on embryo development of two gas atmospheres, $10 \% \mathrm{CO}_{2}: 5 \% \mathrm{O}_{2}: 85 \% \mathrm{~N}_{2}$ or $5 \% \mathrm{CO}_{2}: 95 \%$ air, were examined.

Experiment 2 was a $2 \times 2 \times 4$ factorial study designed to determine if embryo development could be enhanced by adding 0 or $1000 \mathrm{U}$ of mLIF or 0 or $1000 \mathrm{U}$ of recombinant hLIF (Gibco BRL), all with 0 or $10 \%$ FBS in the RD culture medium. This was the only experiment in which FBS was used. Again, the effects on embryo development of two gas atmospheres, $10 \% \mathrm{CO}_{2}: 5 \% \mathrm{O}_{2}: 85 \% \mathrm{~N}_{2}$ or $5 \% \mathrm{CO}_{2}: 95 \%$ air, were examined.

Experiment 3 was a $2 \times 2$ factorial study designed to determine the effects on embryonic development by adding 0 or $1000 \mathrm{U}$ of recombinant hLIF to the RD culture medium. Both two- and 16-cell stage embryos were utilized since the embryonic stage at the time of exposure to hLIF was previously reported to affect devel- 
opment (Fukui and Matsuyama, 1994; Han et al, 1995; Lavranos et al, 1995). Furthermore, the culture interval was increased such that all embryos were cultured until d6 of development, in an effort to discern any effects of hLIF on blastocyst hatching, as had been reported for embryos of the mouse (Robertson et al, 1991; Lavranos et al, 1995), sheep (Fry et al, 1992) and cow (Han et al, 1995). However, the embryos were also examined earlier (d4 of development). The gas atmosphere was $10 \% \mathrm{CO}_{2}: 5 \%$ $\mathrm{O}_{2}: 85 \% \mathrm{~N}_{2}$.

Experiment 4 was a 2 x 2 factorial study where embryos were cultured in medium containing 0 or $5 \mathrm{ng} / \mathrm{mL}$ of PDGF and 0 or $1000 \mathrm{U} / \mathrm{mL}$ recombinant hLIF. Again, embryos were cultured under a gas atmosphere of $10 \% \mathrm{CO}_{2}: 5 \% \mathrm{O}_{2}: 85 \% \mathrm{~N}_{2}$.

\section{Statistical analysis}

Percentages of embryos developing into blastocysts were recorded daily. Following the described culture interval, blastocysts were stained and the number of ICM and TE cells were counted and total cells calculated. Data were analyzed using the general linear models procedure of SAS (1985). Differences among means were detected using the Tukey hsd option, with $P<0.05$ being considered as statistically significant.

\section{RESULTS}

\section{Experiment 1}

Two to four-cell embryos recovered from four donors, cultured in a defined medium supplemented with 0,1 or $5 \mathrm{ng} / \mathrm{mL}$ PDGF and under a gas atmosphere of $10 \% \mathrm{CO}_{2}: 5 \% \mathrm{O}_{2}$ : $85 \% \mathrm{~N}_{2}$ or $5 \% \mathrm{CO}_{2}: 95 \%$ air, developed into morulae or blastocysts with $72 / 82$ (88\%) blastocysts on $\mathrm{d} 4$. Three blastocysts were lost while staining. Cell numbers were greater $(P<0.01)$ for embryos developing under $10 \%$ $\mathrm{CO}_{2}: 5 \% \mathrm{O}_{2}: 85 \% \mathrm{~N}_{2}$ gas atmosphere (fig 1)

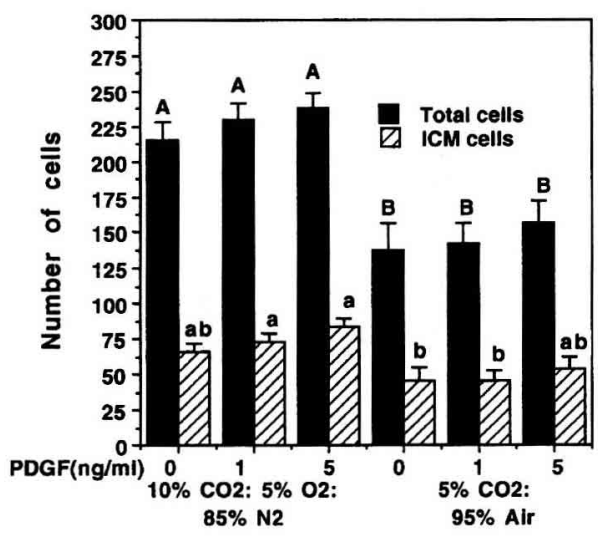

Fig 1. Experiment $1(n=69)$. Effect of 0,1 or $5 \mathrm{ng} / \mathrm{mL}$ platelet-derived growth factors (PDGF) on the number of total cells and inner cell mass (ICM) cells for blastocysts developing in proteinfree $\mathrm{RD}$ medium under $10 \% \mathrm{CO}_{2}: 5 \% \mathrm{O}_{2}: 85 \% \mathrm{~N}_{2}$ or $5 \% \mathrm{CO}_{2}: 95 \%$ air gas atmospheres. Values are expressed as means \pm SEM. Bars with different superscripts (A vs B and a vs b) differ significantly $(P<0.05)$.

compared to $5 \% \mathrm{CO}_{2}: 95 \%$ air (230 total and 75 ICM cells compared to 159 total and 48 ICM cells, respectively). The addition of PDGF had no significant $(P>0.10)$ effect on the number of cells in the blastocysts.

\section{Experiment 2}

Of the 149 two- to four-cell embryos recovered from six donors, 144 (97\%) developed into morulae or blastocysts with $76 \%$ blastocysts on $\mathrm{d} 4$. Four blastocysts were lost while staining. The percentage of embryos developing to the blastocyst stage was not significantly $(P>0.10)$ affected by gas atmosphere, or mLIF, hLIF or $10 \%$ FBS in the culture medium. Cell numbers for blastocysts developing in medium supplemented with mLIF $(n=236)$ were not significantly $(P>0.05)$ different from hLIF $(n=194)$, nor different from the total cell numbers for control blastocysts $(n=224)$. Therefore, data for blastocysts developing in the presence of mLIF or 


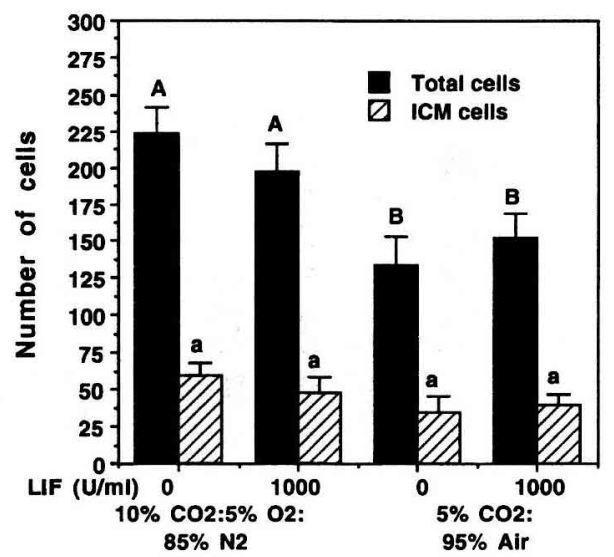

Fig 2. Experiment $2(n=50)$. Effect of 0 or 1 $000 \mathrm{U} / \mathrm{mL}$ mouse (mLIF) or human leukemia inhibitory factor (hLIF) and $10 \% \mathrm{CO}_{2}: 5 \% \mathrm{O}_{2}: 85 \%$ $\mathrm{N}_{2}$ or $5 \% \mathrm{CO}_{2}: 95 \%$ air gas atmospheres on the number of total cells and inner cell mass (ICM) cells for blastocysts developing in RD medium without fetal bovine serum. Values are expressed as means \pm SEM. Bars with different superscripts (A vs $\mathrm{B}$ and a vs b) differ significantly $(P<0.05)$.

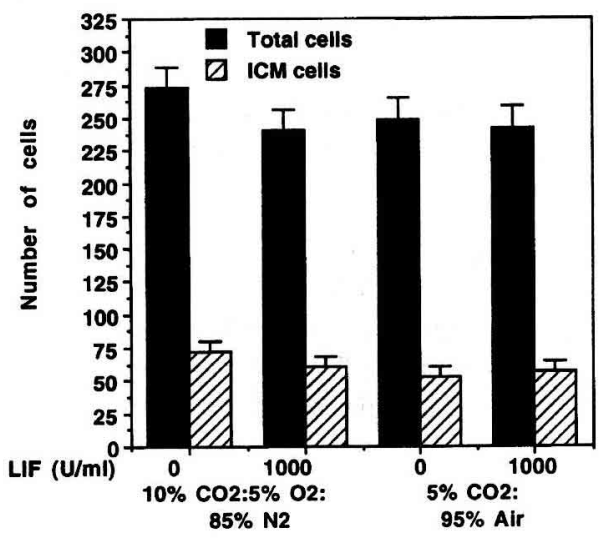

Fig 3. Experiment $2(n=59)$. Effect of 0 to $1000 \mathrm{U} / \mathrm{mL}$ mouse (mLIF) or human (hLIF) leukemia inhibitory factor (hLIF) and $10 \% \mathrm{CO}_{2}: 5 \% \mathrm{O}_{2}: 85 \% \mathrm{~N}_{2}$ or $5 \% \mathrm{CO}_{2}: 95 \%$ air gas atmospheres on the number of total cells and inner cell mass (ICM) cells for blastocysts developing in RD medium with $10 \%$ fetal bovine serum. Values are expressed as means \pm SEM. Bars within total cells and ICM cells were not different $(P>0.10)$.
$\mathrm{hLIF}$ are combined in figure 2 without FBS and in figure 3 with FBS. In the absence of FBS (fig 2), the number of total cells in the blastocysts developing under $10 \% \mathrm{CO}_{2}: 5 \%$ $\mathrm{O}_{2}: 85 \% \mathrm{~N}_{2}$ was greater than for blastocysts under $5 \% \mathrm{CO}_{2}: 95 \%$ air (206 vs $155 ; P<$ 0.05 ). In the presence of FBS (fig 3), there was no effect of gas atmosphere on the number of cells. Figures 2 and 3 also show that the addition of $10 \%$ FBS vs no FBS increased total cell numbers ( 251 vs $176 ; P<0.01)$ as well as the number of ICM cells ( 62 vs 46 ; $P<0.05)$.

\section{Experiment 3}

In experiment 3 , embryos were recovered from 13 donors at the two- to four or 16-cell stage $(n=160)$ and cultured in defined medium without FBS, to compare the treatment of embryos at different stages with hLIF. Development of 16-cell embryos exposed to hLIF was reduced $(P<0.05)$ at $\mathrm{d} 4$ compared to controls (75 vs $98 \%$ blastocysts). Two-cell embryos cultured with hLIF resulted in $100 \%$ blastocysts by $\mathrm{d} 4$ and were greater $(P<0.05)$ than $88 \%$ for controls. Although embryos were cultured to $\mathrm{d} 6$ and then stained and examined for numbers of ICM and TE cells, these counts are not reported because the blastocysts were observed to be undergoing degeneration.

\section{Experiment 4}

In experiment 4,170 two- to four-cell embryos recovered from eight donors and cultured in defined medium supplemented with 0 or $5 \mathrm{ng} / \mathrm{mL}$ PDGF and 0 or $1000 \mathrm{U} / \mathrm{mL}$ hLIF, resulted in $98 \%$ blastocysts. The addition of either PDGF or hLIF or both to the culture medium had no beneficial effect on cell numbers (fig 4). In addition, the percentages of hatching blastocysts on $\mathrm{d} 4$ listed in the same order of treatments shown in fig 4 were 26,39 , 36 and 26 , respectively $(P>0.05)$. 


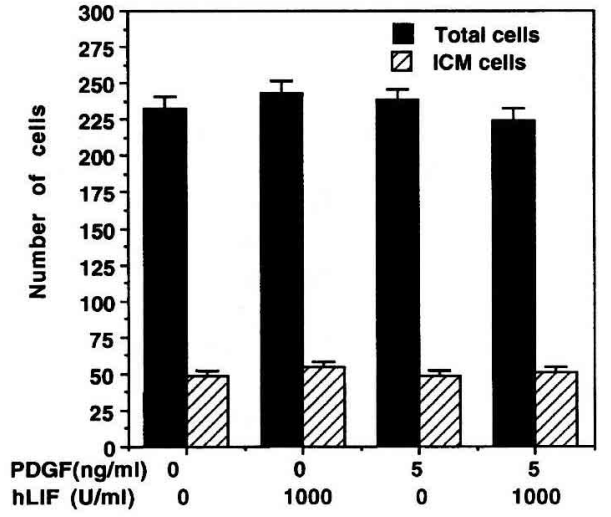

Fig 4. Experiment $4(n=167)$. Effect of 0 or $5 \mathrm{ng} / \mathrm{mL}$ platelet-derived growth factors (PDGF) and 0 or $1000 \mathrm{U} / \mathrm{mL}$ human leukemia inhibitory factor (hLIF) on the number of total cells and inner cell mass (ICM) cells for blastocysts developing in RD medium under a gas atmosphere of $10 \% \mathrm{CO}_{2}: 5 \% \mathrm{O}_{2}: 85 \% \mathrm{~N}_{2}$. Values are expressed as means \pm SEM. Bars within total cells and ICM cells were not different $(P>0.10)$.

\section{DISCUSSION AND CONCLUSION}

Most rabbit embryos cultured in RD medium develop into blastocysts (Carney and Foote, 1991; Hallden et al, 1992; Li and Foote, 1993). However, cell numbers are often compromised compared to embryos developing in vivo (Fischer, 1987; Fischer et al, 1990; Carney and Foote, 1991). Carney and Foote (1990) observed embryos to have a mean of 242 cells at 3.5 days; at d4, Collas et al (1991) found 310 cells and Giles and Foote found 414 cells. In the present study, the number of ICM and TE cells comprising blastocysts developing in RD medium supplemented with growth factors and/or FBS under two gas atmospheres was determined.

In agreement with other studies (Hallden et al, 1992; Li and Foote, 1993; Lindenau and Fischer, 1994; Farrell and Foote, 1995), we observed that the gas atmosphere utilized for rabbit embryo culture affects embryo development. Blastocysts produced under a gas atmosphere of $10 \% \mathrm{CO}_{2}: 5 \% \mathrm{O}_{2}: 85 \% \mathrm{~N}_{2}$, and without serum, had a greater number of total cells than those cultured under $5 \% \mathrm{CO}_{2}$ : 95\% air (figs 1 and 2). The improved development with $10 \% \mathrm{CO}_{2}: 5 \% \mathrm{O}_{2}: 85 \% \mathrm{~N}_{2}$ could be due to the decreased oxygen concentration (Li and Foote, 1993; Lindenau and Fischer, 1994; Farrell and Foote, 1995), or to the increase in carbon dioxide (Hallden et al, 1992). In fact, with rabbit embryos, the improved development is probably the effect of both gases.

In the present study, differences in blastocyst cell numbers due to gas atmosphere were affected by the presence of $10 \%$ FBS. The effect seen in figure 2 without FBS was eliminated when FBS was included (fig 3). One explanation may be that more free radicals are formed in the $5 \% \mathrm{CO}_{2}: 95 \%$ air atmosphere (approximately $20 \% \mathrm{O}_{2}$ ) than when $10 \% \mathrm{CO}_{2}: 5 \% \mathrm{O}_{2}: 85 \% \mathrm{~N}_{2}$ is used and these radicals may be toxic to the embryo in a protein-free medium ( $\mathrm{Li}$ and Foote, 1993). The radicals, however, may be bound or modified by high molecular weight proteins present in FBS and, therefore, differences in embryo development due to gas atmosphere may be reduced or eliminated.

The FBS may provide a variety of growth and other factors. Improved cell numbers for blastocysts were observed if RD medium (fig 2) was supplemented with $10 \%$ FBS (fig 3). In this experiment, the addition of $10 \%$ FBS improved the number of total cells and ICM cells for embryos cultured under $5 \% \mathrm{CO}_{2}$ : $95 \%$ air, but not the ratio between the two. These results are consistent with other reports in which the addition of biological fluids improved embryo cell numbers (Collas et al, 1991).

In the present study, culture medium supplemented with PDGF and/or LIF had no effect on the proportion of embryos developing to the blastocyst stage or on cell numbers (figs $1-4$ ). The differences in response reported here and in the literature could be due to several factors. Species differences 
and differences in culture conditions, including medium, protein source, gas atmosphere and embryo density, may affect embryo response to PDGF and/or LIF supplementation.

In addition, the growth factors utilized were not proteins isolated from rabbits since these were not available. However, we used recombinant human PDGF-BB which has been shown to have biological activity in cultured rabbit gastric epithelial cells (Watanabe et al, 1996) and smooth muscle cells (Fabunmi et al, 1996). Similarly, LIF was detected in the luminal epithelium of the rabbit uterus on d5 of pregnancy using an antibody to recombinant hLIF (Yang et al, 1994).

In conclusion, these studies indicate that the protein-free medium provides a nutrient environment suitable for two-cell embryos to be cultured into a high proportion of blastocysts. The gas atmosphere of $10 \% \mathrm{CO}_{2}: 5 \%$ $\mathrm{O}_{2}: 85 \% \mathrm{~N}_{2}$ enhanced blastocyst development in both total cell numbers and ICM cells, compared with $5 \% \mathrm{CO}_{2}$ : $95 \%$ air. However, development was less than optimal compared to media containing $10 \%$ FBS. Under these conditions, the inclusion of PDGF or LIF did not improve culture conditions of rabbit embryos.

\section{ACKNOWLEDGMENTS}

The authors thank Dr GA Presicce for helpful suggestions and D Bevins for assistance with manuscript preparation. This research was supported in part by the NICHHD National Cooperative Program on Non-human In Vitro Fertilization and Preimplantation Development, funded by NICHHD through Cooperative Agreement HD21939. The follicle-stimulating hormone and luteinizing hormone were supplied by the National Hormone and Pituitary Program, the National Institute of Diabetes and Digestive and Kidney Diseases, the National Institute of Child Health and Human Development and the US Department of Agriculture.

\section{REFERENCES}

Carney EW, Foote FH (1990) Effects of superovulation, embryo recovery, culture system and embryo transfer on development of rabbit embryos in vivo and in vitro. $J$ Reprod Fertil 89, 543-551

Carney EW, Foote RH (1991) Improved development of rabbit one-cell embryos to the hatching blastocyst stage by culture in a defined, protein-free culture medium. J Reprod Fertil 91, 113-123

Collas P, Duby RT, Robl JM (1991) In vitro development of rabbit pronuclear embryos in rabbit peritoneal fluid. Biol Reprod 44, 1100-1107

Colver RM, Howe AM, McDonough PG, Boldt J (1991) Influence of growth factors in defined culture medium on in vitro development of mouse embryos. Fertil Steril 55, 194-199

Fabunmi RP, Baker AH, Murray EJ, Booth RFG, Newby AC (1996) Divergent regulation by growth factors and cytokines of $95 \mathrm{kDa}$ and $72 \mathrm{kDa}$ gelatinases and tissue inhibitors of metalloproteinases$1,-2$ and -3 in rabbit aortic smooth muscle cells. Biochem J 315, 335-342

Farrell PB, Foote RH (1995) Beneficial effects of culturing rabbit zygotes to blastocysts in $5 \%$ oxygen and $10 \%$ carbon dioxide. $J$ Reprod Fertil $103,127-$ 130

Fischer B (1987) Development retardation in cultured preimplantation rabbit embryos. I Reprod Fertil $79,115-123$

Fischer B, Jung T, Hegle-Hartung C, Beier HM (1990) Development of preimplantation rabbit embryos in uterine flushing-supplemented culture media. Mol Reprod Dev 27, 216-223

Flood MR, Gage TL, Bunch TD (1993) Effect of various growth-promoting factors on preimplantation bovine embryo development in vitro. Theriogenology 39, 823-833

Fry RC, Batt PA, Fairclough RJ, Parr RA (1992) Human leukemia inhibitory factor improves the viability of cultured ovine embryos. Biol Reprod $46,470-474$

Fukui Y, Matsuyama K (1994) Development of in vitro matured and fertilized bovine embryos cultured in media containing human leukemia inhibitory factor. Theriogenology 42, 663-673

Giles JR, Foote RH (1995) Rabbit blastocyst: allocation of cells to the inner cell mass and trophectoderm. Mol Reprod Dev 41, 201-211

Hallden K, Li J, Carney EW, Foote RH (1992) Increasing carbon dioxide from five percent to 
ten percent improves rabbit blastocyst development from cultured zygotes. Mol Reprod Dev 33 , 276-280

Han YM, Lee ES, Mogoe T, Lee KK, Fukui Y (1995) Effect of human leukemia inhibitory factor on in vitro development of IVF-derived bovine morulae and blastocysts. Theriogenology 44, 507-516

Handyside AH, Hunter S (1984) A rapid procedure for visualizing the inner cell mass and trophectoderm nuclei of mouse blastocysts in situ using polynucleotide-specific fluorochromes. J Exp Zool 231, 429-434

Kane MT (1987) In vitro growth of preimplantation rabbit embryos. In: The Mammalian Preimplantation Embryo: Regulation of Growth and Differentiation In Vitro (BD Bavister, ed), Plenum Press, New York, USA, 193-218

Kennelly JJ, Foote RH (1965) Superovulatory response of pre- and post-pubertal rabbits to commercially available gonadotrophins. $J$ Reprod Fertil 9,177 188

Larson RC, Ignotz GG, Curie WB (1992) Platelet derived growth factor (PDGF) stimulates development of bovine embryos during the fourth cell cycle. Development 115,821-826

Lavranos TC, Rathjen PD, Seamark RF (1995) Trophic effects of myeloid leukaemia inhibitory factor (LIF) on mouse embryos. $J$ Reprod Fertil 105, 331-338

Li J, Foote RH (1993) Culture of rabbit zygotes into blastocysts in protein-free medium with one to twenty per cent oxygen. $J$ Reprod Fertil 98,163 167

Lindenau A, Fischer B (1994) Effect of oxygen concentration in the incubator's gas phase on the development of cultured preimplantation rabbit embryos. Theriogenology 41, 889-898

Murray R, Lee F, Chiu CP (1990) The genes for leukemia inhibitory factor and interleukin- 6 are expressed in mouse blastocysts prior to the onset of hemopoiesis. Mol Cell Biol 10, 4953-4956
Rappolee DA, Brenner CA, Schultz R, Mark D, Werb $Z$ (1988) Developmental expression of PDGF, TGF- $\alpha$, and TGF- $\beta$ genes in preimplanation mouse embryos. Science 241, 1823-1825

Robertson SA, Lavranos TC, Seamark RF (1991) In vitro models of the maternal fetal interface. In: The Molecular and Cellular Immunology of the Maternal-Fetal Interface (TG Wegmann, E Nisbett-Brown, TJ Gill, eds), Oxford University Press, New York, USA, 191-206

SAS Institute Inc (1985) SAS User's Guide: Statistics. Carey, NC, USA

Schultz GA, Heyner S (1993) Growth factors in preimplantation mammalian embryo. Oxford Rev Reprod Biol 15, 43-81

Stewart CL (1994) Leukaemia inhibitory factor and the regulation of pre-implantation development of the mammalian embryo. Mol Reprod Dev 39, 233238

Thibodeaux JK, Del Vecchio RP, Hansel W (1993) Role of platelet-derived growth factor in development of in vitro matured and in vitro fertilized bovine embryos. J Reprod Fertil 98, 61-66

Watanabe S, Wang XE, Hirose M, Oide H, Kitamura T, Miwa H, Miyazaki A, Sato N (1996) Plateletderived growth factor accelerates gastric epithelial restoration in a rabbit cultured cell model. Gastroenterology 110,775-779

Watson AJ, Hogan A, Hahnel A, Wiemer KE, Schultz GA (1992) Expression of growth factor ligand and receptor genes in the preimplantation bovine embryo. Mol Reprod Dev 31, 87-95

Yang BK, Yang X, Foote RH (1993) Effect of growth factors on morula and blastocyst development of in vitro matured and in vitro fertilized bovine oocytes. Theriogenology 40, 521-530

Yang Z, Le S, Chen D, Harper MJK (1994) Temporal and spatial expression of leukemia inhibitory factor in rabbit uterus during early pregnancy. $\mathrm{Mol}$ Reprod Dev 38, 148-152 